\title{
STRATEGI KOMUNIKASI PENYULUHAN PT. AGRO SINERGI NUSANTARA DALAM MENGSOSIALISASIKAN PERJANJIAN KERJA BERSAMA TERHADAP KARYAWAN KEBUN UJUNG LAMIE
}

\author{
Cut Wita ${ }^{1}$; Putri Maulina ${ }^{2}$ \\ Universitas Teuku Umar, Indonesia \\ E-mail: cutwita49@gmail.com ${ }^{1}$; putrimaulina@utu.ac.id ${ }^{2}$
}

\begin{abstract}
Abstrak
Strategi komunikasi penyuluhan PT. Agro Sinergi Nusantara dalam mensosialisasikan Perjanjian Kerja Bersama (PKB) oleh direksi PT. Agro Sinergi Nusantara (PT. ASN) dengan menjalankan aspek perencanaan komunikasi meliputi pengenalan internal perusahaan dan eksternal perusahaan, penyusunan materi penyuluhan, menetapkan metode, serta memilih media komunikasi dalam rangka menjalankan kegiatan melalui sosialisasi Perjanjian Kerja Bersama menggunakan strategi komunikasi yang tepat sasaran. Dalam penelitian ini peneliti memakai tekhnik deskriptif kualitatif, dengan pengumpulan data melalui observasi, wawancara dan dokumentasi berbentuk tulisan sebagai data primer, data sekunder. Kemudian teknik analisa yang dipakai dalam penelitian tersebut ialah analisa data kualitatif memakai model Analisa interaktif Miles dan Huberman.
\end{abstract}

Kata Kunci: Komunikasi, Strategi Komunikasi, Sosialisasi.

\begin{abstract}
PT. Agro sinergi nusantara in disseminating the collective labor agreement (PKB) by the directors of PT. Agro sinergi nusantara (PT. ASN) by carrying out aspects of communication planning including introduction of the company's internal and external companies, preparation of extension materials, determining methods, and selecting communication media in order to implement activities through the socialization of collective labor agreements using well-targeted communication strategies. In this study, researchers used a qualitative descriptive technique. With data collection through observation, interviews and written documentation as primary data, secondary data. Then the analytical technique used in this study is qualitative data analysis using the miles and huberman interactive analysis model.
\end{abstract}

Keyword: Communication, Communication Strategy, Socialization.

\section{PENDAHULUAN}

Rancangan pengembangan dalam memajukan perusahaan perkebunan kelapa sawit sebagai mitra dalam skala besar bisa memberi keuntungan baik itu 
pihak swasta ataupun pemerintah karena akan berdampak pada pertumbuhan perekonomian, sosial masyarakat dan menciptakan lowongan kerja yang baru terhadap pengangguran, adanya perusahaan kelapa sawit diberbagai daerah bisa mendukung industri dalam negeri demi menciptakan berbagai olahan produk yang dihasilkan oleh kelapa sawit. Salah satu contohnya minyak makan, pupuk dan sebagainya.

PT. Agro Sinergi Nusantara merupakan perkebunan kelapa sawit dibawah naungan (BUMN) yang telah beroperasional di Aceh, salah satunya yang ada di Ujung Lamie. Berdasarkan surat kementerian BUMN nomor S-817/MBU/2008 tanggal 28 Desember 2010 tentang Persetujuan Pendirian Perusahaan Patungan antara PT. Perkebunan Nusantara I (Persero) dan PT. Perkebunan Nusantara IV (Persero). ${ }^{1}$ Dalam menjalankan kegiatan kerjasama pihak PT. Perkebunan nusantara IV (Persero) berhak untuk mengatur struktur kepemimpinan untuk menjalankan kegiatan perkebunan dengan baik dan lancar.

Oleh karena itu, diperlukan sebuah strategi komunikasi yang menjadi rangkaian proses untuk menciptakan terobasan baru dalam mencapai hasil yang telah direncanakan, jika communication telah dilaksanakan dengan benar maka perolehan hasil yang dicapai juga akan berhasil dengan baik. Dalam melakukan strategi komunikasi perlu dianalisis dengan pemetaan secara memadai berbagai perihal yang ada, dan dalam menetapkan strategi harus dengan hati-hati demi rencana communication yang benar.

Hadirnya akses informasi pada media sosial di era moderen seperti sekarang lebih beragam dan bervariasi. Internet dapat diakses oleh segala lapisan masyarakat dan terbuka luas untuk mendapatkan berbagai informasi. Perubahan yang berlaku, memberikan peluang seluas-luasnya bagi siapa saja, untuk mendapatkan informasi maupun menyebarluaskan informasi secara cepat dalam ruang tanpa batas. Fasilitas ini dapat dimanfaatkan bagi penyuluh dalam menjalankan peran dan fungsi penyuluh untuk menjadi media belajar dan membantu memecahkan permasalahan yang terjadi dilapangan.

${ }^{1}$ Surat kementerian BUMN nomor S-817/MBU/2008 tanggal 28 Desember 2010 tentang Persetujuan Pendirian Perusahaan Patungan antara PT. Perkebunan Nusantara I (Persero) dan PT. Perkebunan Nusantara IV (Persero) 
Dengan tingkat sosialiasi yang dilaksanakan, sebagai bentuk kepedulian partisipatif dari pihak perusahaan untuk beradaptasi dengan masyarakat, seperti bersosilisasi berkaitan dengan suatu perencanaan yang akan dilaksanakan. ${ }^{2}$ Perusahaan bisa berhasil atau berkembang apabila mampu beradaptasi dengan lingkungan wilayah tempat perusahaan itu di dirikan, bentuk perkembangan dalam meningkatkan perekonomian, strata sosial yang terjadi dimasyarakat perusahaan harus lebih paham bahkan dapat memberi respon dengan bijak kepada pekerja dan masyarakat disekitar area perusahaan. Salah satu aspek penting misalnya perusahaan mampu malaksanakan Perjanjian Kerja Bersama (PKB) sebagai keharusan yang dilakukan oleh pihak perusahaan untuk menjamin karyawan dalam bekerja, dan hal tersebut perlu untuk disosialisasikan secara baik.

Sehingga, perlu ada peran public relations atau tim penyuluhan dari perusahaan menjadi ujung pertahanan dari perusahaan untuk memperkokoh stabilitas kegiatan dari suatu perusahaan. Tim penyuluhan dari PT harus lebih memerhatikan eksitensi suatu perusahaan agar perusahaan bisa mencapai tujuan yang diinginkan. Komunikator perusahaan harus lancar dalam memberikan informasi kepada publik untuk terjalinnya hubungan baik dengan masyarakat. Berdasarkan observasi yang peneliti lakukan, sementara ini belum terpantau dengan jelas terkait langkah yang dilakukan perusahaan dalam sosialisasi Perjanjian Kerjasama Bersama (PKB) terhadap karyawan kebun di Ujung Lamie, maka penulis tertarik mengkaji "Strategi komunikasi penyuluhan PT. Anggro Nusantara Sinergi dalam mensosialisasikan perjanjian kerjasama terhadap karyawan kebun Ujung Lamie"

\section{KAJIAN DAN PEMBAHASAN}

\section{A. Landasan Teori}

\section{Communication}

Secara umum, komunikasi dapat didefinisikan sebagai proses berinteraksi dengan dua orang atau lebih dalam menyampaikan pesan. Adapun di dalam interaksi proses communication terdapat unsur pesan antara pengirim dan penerima pesan melalui media. Effendy menjelaskan ada beberapa komponen indikator

\footnotetext{
${ }^{2}$ Effendy (2016). Sosialasi Administrasi Publik, 203.
} 
komunikasi yang mencakup secara keseluruhan, ${ }^{3}$ yaitu: komunikator, pesan, komunikan, saluran (media), dan umpan balik (feed back). Dan setiap unsur dalam komponen komunikasi yang ada, erat kaitannya dengan langkah-langkah (cara) yang tepat dalam pelaksanaan sebuah komunikasi atau sering kita pahami sebagai strategi dalam berkomunikasi.

\section{a. Strategy Communication}

Strategi komunikasi merupakan proses yang dilakukan oleh satu atau dua orang bahkan lebih dari dua orang dalam menyampaikan pesan dengan berbagai macam cara untuk menarik perima pesan dan pesannya harus jelas makna yang ingin disampaikan, tidak berbelit dan tepat sasaran.

b. Tujuan Strategy Communication

Di dalam konsep strategy Communication menurut Peterson terdapat tiga tujuan Strategy Communication yaitu: ${ }^{4}$

1) To secure understanding, memastikan komunikan faham akan pesan yang diterima.

2) To establish acceptance, penerima pesan harus dijelaskan dengan detail pesan yang ingin disampaikan.

3) To motive action Penggiatan untuk memotivasinya.

\section{c. Hambatan Strategy Communication}

Dalam menyusun suatu strategy communication perlu dilihat pada beberapa faktor pendukung dan penghambat, dari komponen yang perlu dilakukan secara teliti pada saat penyusunan strategy communication adalah:

1) Sasaran komunikasi harus tepat, siapa, dimana dan mengapa memilih sasaran tersebut.

2) Mengkaji lebih dulu pesan komunikasi yang hendak disampaikan.

3) Memilih media komunikasi yang akurat.

Kemudian dalam memahami peran seorang communicator pada saat menyampaikan pesan/berkomunikasi dan memahami faktor-faktor dari

\footnotetext{
2013), 34.

${ }^{3}$ Onong Ucjhana Effendy, Perencanaan Dan Strategi Komunikasi. (Jakarta: PT. Kencana,

${ }^{4}$ Menurut R. Wayne Pace, Brent D. Peterson, dan M. Dallas Burnett menyatakan bahwa strategi komunikasi memiliki 3 (tiga) tujuan, yaitu (Effendy, 1984: 35-36)
} 
communicant yang berpengaruh terhadap kelancaran berkomunikasi juga penting dilakukan, yaitu ada dua: Source Attraction (Daya tarik sumber), dan Source Credibility (Kredibilitas Sumber).

\section{Sosialisasi}

Sosialisasi merupakan cara untuk menyukseskan suatu perencanaan yang telah direncanakan oleh perusahaan, agar program tersebut berjalan dengan lancar perlu adanya strategi yang benar-benar akurat dalam pelaksanaannya. Uchjana mengatakan kelancaran suatu rancangan perlu adanya Good Communication terhadap pekerja demi mencapai tujuan yang dinginkan perusahaan. ${ }^{5}$ Menurut Placet, strategi merupakan perencanaan yang bisa mengatur sumber daya manusia dengan kemampuan yang diberikan kepada perusahaan dalam mencapai sebuah tujuan. $^{6}$

\section{Petugas Penyuluh Perusahaan}

Perencanaan yang dilakukan oleh komunikan dalam menentukan langkah supaya bisa mencapai satu tujuan tertentu. Penyuluh Perusahaan merupakan perwakilan perusahaan dalam menjalankan program yang telah direncanakan oleh perusahaan. Tugas dari penyuluh perusahaan sebagai komunikator, edukator, fasilitator, mediator, dan motivator. Sedangkan ruang lingkup Peran Team Penyuluhan antara lain: 1) Sebagai date communication (pengirim dan penerima informasi), 2) Sebagai Fasilitator, 3) Sebagai Konsultan, 4) Sebagai Supervisi/Pembinaan, dan 5) Sebagai Monitoring dan Evaluasi.

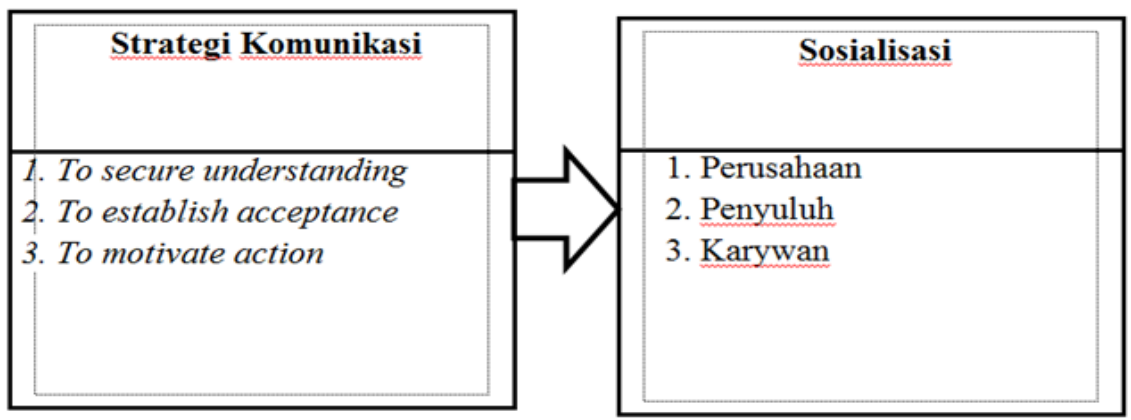

\section{Gambar: 1. Kerangka Pemikiran}

\footnotetext{
${ }^{5}$ Ucjhana 2014. Perencanaan Dan Strategi Komunikasi. Jakarta

${ }^{6}$ Placet.2016. Perspektif Perjanjian Kerja Bersama Dalam Memotivasi Pekerja. vol. 6 no.
} 1. hal 7 


\section{Perjanjian Kerja Bersama}

Mengadakan audiensi antara pimpinan perusahaan dengan pimpinan serikat pekerja (buruh) terhadap persoalan yang terjadi dan guna mencari hasil akhir dari suatu permasalahan yang terjadi serta berkaitan prioritas pekerja dan untuk tujuan perusahaan. PKB sebuah perjanjian dari hasil kesepakatan antara Serikat Pekerja yang tercatat di organisasi pemerintahan yang bertanggungjawab pada bidang ketenagakerjaan dengan pengusaha. ${ }^{7}$

Perjanjian kerja pada kurun waktu tertentu bisa memperpanjangkan masa kerjanya dengan kata lain diperbarui oleh perusahaan. Artinya perusaaan tidak melakukan kesalahan dengan melanggar aturan hokum untuk pekerja yang sudah mendapatkan kontrak. Berikut perjanjian kerja bersama dibuat atas dasar: 1) Kesepakatan antara kedua belah pihak, 2) Kemampuan untuk melakukan perbuatan hukum. 3) Adanya pekerjaan yang diperjanjikan. 4) Pekerjaan perjanjian tidak bertentangan dengan ketertiban umum, dan peraturan perundang-undangan.

a. Manfaat Perjanjian Kerja Bersama

Manfaat yang diperoleh dari Perjanjian Kerja Bersama dalam memudahkan karyawan dalam bekerja, berikut ini:

1) Memudahkan karyawan untuk membuat perjanjian kerja.

2) Sebagai jalan keluar atau way-out dalam hal perundang-undangan ketenagakerjaan.

3) Sebagai sarana untuk menciptakan ketenangan kerja bagi karyawan dalam kelangsungan usaha bagi perusahaan.

b. Akhir dari Perjanjian Kerja Bersama

Pengakiran perjanjian kerja bersama setelah adanya keputusan dari pihak pengadilan serta penetapan lembaga penyelesaian perselisihan hubungan industrial yang telah mempunyai kekuatan hukum tetap, selanjutnya jika adanya kejadian yang tertulis dalam perjanjian kerja bersama di salahgunakan maka perjanjian kerja juga bisa berakhir dan pengakhiran kerja bersama juga bisa disebabkan oleh meninggal dunia pekerja.

7 Tobing dan Buwana. 2016. Perspektif Perjanjian Kerja Bersama untuk Motivasi Karyawan, 6. 


\section{B. Metodologi}

Penelitian yang peneliti lakukan yaitu dengan teknik deskriptif Kualitatif dengan metode observasi, wawancara, dan dokumentasi berbentuk tulisan atau mempelajari tentang fenomena tertentu. ${ }^{8}$ Tempat dan Waktu Penelitian yaitu pada Perusahaan PT. Agro Sinergi Nusantara Ujung Lamie Nagan Raya. Tujuan peneliti mengambil objek penelitian ini yaitu untuk lebih mudah mendapatkan data. Waktu penelitian lebih kurang 1 bulan dimulai pada bulan Juni-Juli 2021.

\section{Sumber Data Penelitian}

Dalam mengambil data penelitian, peneliti melaksanakan pengumpulan data dalam bentuk data primer dan data sekunder yaitu sebagai berikut;

a. Data Primer didapatkan lansung dari narasumber yang dilakukan oleh peneliti dengan teknik pengumpulan data. 1) Observasi, 2) Wawancara, 3) Dokumentasi.

b. Data Sekunder didapatkan dari pihak luar atau tidak secara tidak langsung, seperti laporan, buku, jurnal dan artikel terkait.

\section{Teknik Dalam Mengambil Data}

Purposive sampling memilih responden yang memahami suatu masalah yang terjadi di lapangan. Langkah dalam mengambil data dengan pertimbangan tertentu, seperti melakukan wawancara mendalam dari satu informan ke informan lainnya, hingga peneliti tidak menemukan jawaban baru dari orang lain. ${ }^{9}$

\section{Pengumpulan Data}

Untuk memperoleh data lengkap peneliti menggunakan metode pengumpulan data, menurut Sugiyono yang dilakukan dengan cara seperti: ${ }^{10}$

a. Wawancara; Pengumpulan data yang peneliti pakai guna memperoleh jawaban dengan cara memberikan pertanyaan lansung dengan informan.

\footnotetext{
${ }^{8}$ Burhan Bungin, Penelitian Kualitatif: Komunikasi, Ekonomi, Kebijakan Publik dan Ilmu Sosial Lainnya. Jakarta (ID): Kencana.

${ }^{9}$ Sugiyono, 2016; Metode penelitian kualitatif, (Bandung: Alfabeta, 2016), 87.

10 Sugiyono, Metode Penelitian Kuantitatif, Kualitatif dan R\&D, (Bandung: Alfabeta, 2013), cet ke-19, 224.
} 
b. Observasi; Pengamatan sementara untuk mengamati aktivitas atau fenomena yang dilakukan secara sistematis.

c. Purposive Sampling; Sampel yang diambil dengan berdasarkan pertimbangan yang subjektif, yaitu informan telah ditentukan sendiri ditentukan oleh peneliti.

\section{Penentuan Informan}

Informan sebagai narasumber bertujuan untuk memperoleh jawaban dari judul yang sedang diteliti dan dianggap mempunyai data yang dibutuhkan dalam penelitian. Alasan peneliti memilih narasumber yaitu untuk mengetahui permasalahan terjadi di lapangan sehingga bisa berbagi informasi yang terjadi dilapangan, subjek pada penelitian ini ialah bagian SDM dan Umum yang telah terlibat.

\begin{tabular}{|l|l|l|}
\hline No. & Nama Informan & Jabatan \\
\hline 1 & Maddelisna & Subbag SDM \\
\hline 2 & Feri Yanti & Subbag Umum \\
\hline
\end{tabular}

(Sumber: Data Penelitian, 2021)

\section{Analisa Data}

Penelitian ini analisa yang digunakan ialah analisis deskriptif, yaitu fenomena yang terjadi di lapangan dengan sistematys, akurat tentang fenomena yang sedang diteliti oleh peneliti. ${ }^{11}$

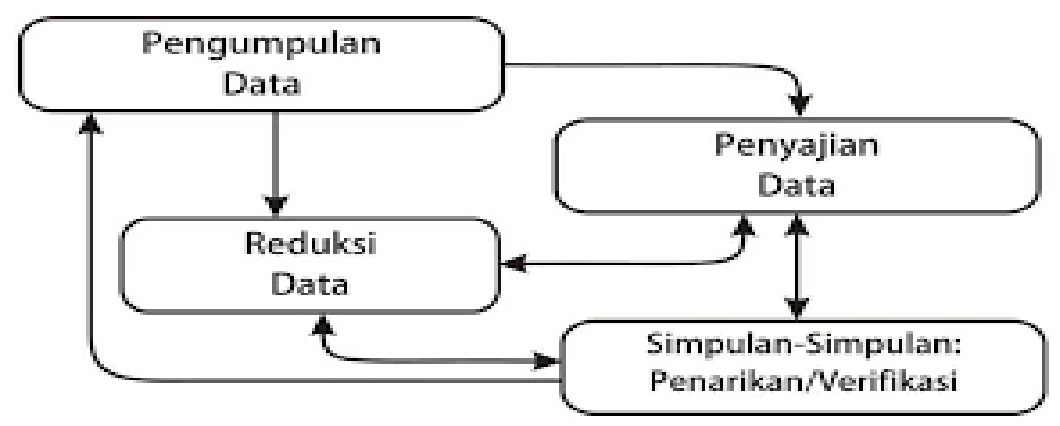

Gambar 1. Model Analisis Interaktif Miles dan Huberman 1992, hlm. 16 
a. Pengumpulan data di objek penelitian dengan observasi, wawancara dan dokumentasi.

b. Reduksi data, yaitu menyimpulkan, mengarahkan, agar memperoleh hasil akhir dan penelitian.

c. Penyajian data, yaitu kegiatan menyimpulkan data yang telah direduksi.

Penarikan kesimpulan (verifikasi), yaitu hasil akhir pada penelitian sehingga memperoleh kesimpulan

\section{Hasil Dan Pembahasan}

Communication merupakan kecakapan dasar perorangan yang dilakukan dari satu dengan dua orang bahkan lebih dari dua yang saling berhubungan satu dengan yang laindi kehidupan sehari-hari. Baik itu di tempat kerja, dalam bermasyarakat bahkan dimana saja orang berada. Communication merupakan suatu tindakan dalam suatu penyampaian pesan dari pengirim ke penerima pesan.

\section{Strategi Komunikasi Penyuluhan}

Strategi komunikasi penyuluhan di PT. Agro Sinergi Nusantara (PT. ASN) Subbag Hubungan Masyarakat yaitu membuat perubahan positif dalam bertanggung jawab dan tingkat sosial perwakilan perusahaan dengan pekerja dalam mengapai tujuan yang telah di tetapkan. Berikut beberapa pendekatan yang dilakukan oleh perusahaan;

a) Pendekatan strategi operasional,

b) Pendekatan kerjasama,

c) Pendekatan persuasif,

Kemudian strategy yang dijalankan humas PT. Agro Sinergi Nusantara (PT. ASN) sesuai situasi, kondisi untuk mengetahui strategy communication dalam melakukan sosialisasi terhadap kerja kemitraan pada public internal PT. Agro Sinergi Nusantara. Pelaksanaan sosialisasi yang berikan oleh pemberi pesan harus terlebih dahulu melihat waktu, tempat serta masyarakat yang hadir dalam mengikuti sosialisasi.

Strategy communication yang dalam melaksanakan sosialisasi harus adanya dukungan dari semua pihak terutama pihak perusahaan dan adanya dukungan dari masyarakat sehingga sosialisasikan akan terwujud dan terlaksana dengan baik. 
penunjukan prilaku communicator bisa memberikan pembedaan penyampaian pesan dari media serta share sesuai kebutuhan yang diperlukan.

a) Operasional Strategy.

Pelaksanaan perencanaan hubungan masyarakat pada pelaksanaan dengan kemasyarakatan melalui mekanisme cultural social terhadap nilai-nilai yang diberlakukan pada lingkup masyarakat. Berikut langkah strategi operasional yang dijalankan humas PT. Agro Sinergi Nusantara hasil interview yang dilakukan oleh peneliti;

1) Publikasi agenda, informasi ke e-media,

2) Sosialisasi bersama mitra utama PT. Agro Sinergi Nusantara

3) Seminar dan workshop berkaitan Perjanjian Kerja Bersama (PKB), untuk melihat seberapa paham tentang Perjanjian Kerja Bersama.

4) Penilaian kredibilitas komunikator serta isi pesan sosialisasi program kemitraan PT. Agro Sinergi Nusantara dengan aspek opini, aspek persepsi, aspek afeksi, dan aspek tindakan peserta yang mengikuti sosialisasi terhadap bermitra usaha.

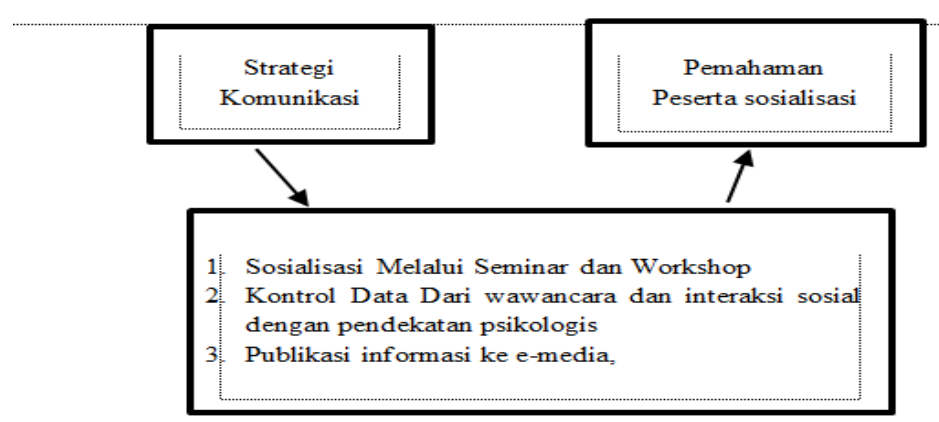

Gambar 2. model implementasi strategi operasional PT. AgroSinergi Nusantara

b) Pendekatan Kerjasama

Upaya Subbag humas dalam menjalin silaturahmi dengan berbagai kalangan dalam pengembangan kemitraan.

c) Pendekatan bersifat Edukatif dan Persuasif

Pendekatan untuk menghasilkan communication timbal balik yaitu penyebaran informasi yang bersifat positif dengan melaksanakan pendekatan persuasif, demi terciptanya menghargai, pemahaman, dan 
toleransi sesama perusahaan.

d) Pendekatan Tanggung Jawab

Sosialisasi strategi ini membiasakan tanggung jawab sosial dengan tujuan dan sasaran hendak diperoleh untuk keuntungan bersama.

\section{Penyuluh Perusahaan}

Suatu perusahaan wajib memiliki kaki tangan atau orang kepercayaan yang benar-benar mampu dipercaya dan bisa membawa kemajuan terhadap perusahaan, hal ini diperuntuk oleh PT. Agro Sinergi Nusantara yang menujukkan tim penyuluh dari perusahaan sebagai salah satu cara untuk mencapai tujuan kemajuan perusahaan, baik itu dalam menyampaikan informasi secara rahasia maupun untuk umum (informasi terhadap karyawan), penyuluh adalah perwakilan peurusahaan untuk mengirim, menerima pesan dari perusahaan, karyawan bahkan dalam bekerja sama dengan pihak-pihak lain untuk kemajuan perusahaan nya. Berikut beberapa tugas yang dilakukan oleh team penyuluh perusahaan diantaranya:

a) Sebagai Fasilitator

Strategy communication dipakai oleh pihak perusahaan ialah comunican secara human relation yaitu mengarahkan, mengawasi, melakukan bimbingan berkaitan dengan usaha dan sebagai penghubung pekerja dan perusahaan. Fasilitas yang diberikan perusahaan adalah sikap petugas penyuluh, seperti melakukan pengawasan dalam bekerja, menyampaikan informasi lain yang berkaitan dengan perusahaan,

b) Sebagai Edukator

Petugas memberikan suatu informasi atau pesan berkaitan dengan pekerjaan, adanya tim penyuluh dari perusahaan diharapkan bisa memberi dampak yang positif dan mampu membawa perubahan kemajuan yang berkelanjutan terhadap suatu perusahaan, dan mampu memberikan dampat positif terhadap para karyawan yaitu untuk memberikan pengetahuan berkaitan dengan pekerjaa nya.

c) Sebagai Motivator

Petugas berkewajiban untuk memberi dorongan, masukan dan motivasi terhadap karyawan untuk menumbuh kembangkan kemampuan diri atau 
skill yang dimiliki oleh setiap pekerja, yaitu turun langsung ke lapangan untuk melihat aktivitas para pekerja.

\section{Strategi Komunikasi dalam Pemanfatan Media Informasi di Era Digital}

Adanya informasi berbasis dengan media oleh sangat membantu semua pihak dalam memajukan perusahaannya dengan adanya teknologi telekomunikasi pada suatu perusahaan pastinya membawa dampak positif terhadap berbagai kalangan terutama pihak perusahaan kemudian pihak karyawan. Untuk memenuhi kebutuhan informasi yang diberikan oleh perusahaan dalam penyampaian pesan akan lebih mudah tim penyuluh dalam memberi informasi terhadap karyawan. Adanya teknologi informasi sudah dimanfaatkan dengan baik oleh penyuluh PT. Agro Sinergi Nusantara dalam mengakses informasi berkaitan dengan perkebunan sawit maupun sebagainya. Hadirnya media online sangat memudahkan pihak perusahaan terutama penyuluh dari perusahaan dalam menyamapaikan beberpa informasi, atau bersosialisasi secara virtual melalui media melalui gadget, laptop dan $p c$.

Agar lebih detailnya dalam pemanfaatan kegiatan penyuluhan yang berbasis teknologi informasi yaitu sebagai berikut:

\section{a) Teknik Communication}

Menyampaiakan suatu pesan/informasi dengan efektif, efesien tepat waktu kepada karyawan sehingga pesan yang disampaikan tepat sasaran. Strategy communication yang penyuluh gunakan dapat kita lihat dari cara menyampaikan suatu informasi/pesan.

b) Saluran Communication

Sebagai media dalam menyampaikan informasi yang diperlukan kepada pihak yang bekerja sama dengan perusahaan tersebut dan juga dengan karyawan. Media communication merupakan hal yang perlu dikedepankan dari komunikasi yang berlangsung, karena mempunyai kaitan erat dengan informasi yang disampaikan.

c) Pengukuran Strategy Communication

Salah satu pesan communication bisa diperhatikan melalui kesesuaian isi pesan yang disampaikan kepada karyawan, sehingga informasi yang 
dibagikan oleh penyuluh terhadap karyawan lebih bisa dipahami dengan jelas. Tujuan dibangunnya communication oleh penyuluh supaya bisa menjadi feedback antara penyuluh dengan pihak lain.

d) Penggunaan Media Internet

Peran teknologi dalam kehidupan sehari-hari sangatlah penting, terlebih lagi pada saat mengembangkan kemajuan suatu perusahaan perkebunan sawit, kecanggihan teknologi bukan hanya pada alat perkebunan saja akan tetapi pada penyampaian suatu informasi juga lebih akurat dan tepat sasaran, tidak harus menunggu lama. Contoh dari teknologi informasi communcation yaitu internet dengan menyajikan berbagai pesan informasi tanpa adanya batasan.

\section{Perjanjian Kerja Bersama (PKB)}

Peraturan perusahaan dengan ketentuan kewenangan, kewajiban pengusaha, serta kewajiban dan hak karyawan. Peraturan perusahaan ditulis dengan satu pihak yaitu pengusaha tanpa konsultasi terlebih dahulu dengan karyawan, selanjutnya baru dilgalkan oleh pemerintah.

Prosedur penyusunan PKB antara pengusaha dengan karyawan yaitu meliputi tahapan berupa:

a) Karyawan kebun Ujung Lamie melakukan aundiensi internal.

b) Permohonan PKB telebih dahulu membuat janji dengan manajemen perusahaan.

c) Pelaksanaan audiensi PKB pengusaha dan pekerja.

d) Dukungan dari hasil audiensi.

e) Pimpinan perusahaan mengesahkan PKB.

f) Mendaftarkan PKB ke dinas tenaga kerja

g) Pelaksanaan PKB dengan pihak terkait.

Perjanjian kerja bersama dapat mebantu memotivasi karywan sejak awal pekerja bergabung dengan perusahaan dan cara membuat perjanjian kerja bersama secara tertulis. Perjanjian kerja bersama mampu memotivasi pekerja dikarenakan apa yang menjadi kebutuhan-kebutuhan utama pekerja telah diatur dan dijelaskan dengan kesepakatan kedua belah pihak.

Dukungan dalam menyusun perjanjian kerja bersama di PT. Agro Sinergi Nusantara, adanya sosialisasi yang dilakukan oleh penyuluh perusahaan terhadap 
karyawan maupun masyarakat biasa. Adanya payung hukum dari advokad yaitu ahli hukum berkaitan dengan penyusunan PKB; adanya puk pada PT. Agro Sinergi Nusantara; kemudian Disnaker Kabupaten Nagan Raya mendukung penuh program PKB.

\section{Sosialisasi}

PT. Agro Sinergi Nusantara telah melakukan sosialisasi terkait PKB terhadap karyawan dan sudah berjalan dengan baik, dari hasil wawancara yang peneliti lakukan dengan pihak perusahaan, bahwasanya pihak perusahaan melakukan sosialisasi tatap muka serta melalui media massa untuk merealisasikan PKB, hal ini berdampak positif baik itu dari pimpinan perusahaan maupun seluruh karyawan perusahaan. Ada beberapa cara untuk bisa menggerakkan public diantaranya;

a) Pengenalan akan permasalahan yang dihadapi.

b) Pengenalan mengenai hambatan yang terjadi.

c) Tingkat keterlibatan public.

Sosialisasi merupakan suatu aktivitas communication dalam mengkomunikasikan suatu informasi yang hendak disampaikan, dalam suatu perusahaan baik itu swasta maupun pemerintah strategy communication sangat diutamakan demi kesuksesan suatu program atau kegiataan dari suatu perusahaan. PT. Agro Sinergi Nusantara telah menerapkan system sosialisasi melalui tatap muka dan media online. Adanya dua tatanan pada saat menentukan hasilyang di inginkan dalam melakukan sosialisasi:

1) Komunikasi Tatap Muka

Dilakukan oleh penyuluh terhadap peserta sosialisasi dalam menyampai program atau suatu kegiatan yang hendak dilaksanakan oleh perusahan, maka demi mencapai hasil yang baik dan adanya dukungan dari semua pihak, perusahaan haruslah melakukan sosialisasi secara terbuka demi kelancaran suatu kegiatan.

2) Komunikasi Bermedia

Banyak perusahaan yang menggunakan media communication sebagai sarana dalam bersosialisasi dengan efektif, efesien dan hemat waktu dengan 
melakukan communication yang informatif. Untuk menyampaikan pesan atau informasi dengan cepat, media teknologi bisa digunakan dengan segera tampa perlu lansung terjun ke lapangan, tergantung dari situasi dan kondisi yang diharapkan oleh perusahaan.

\section{KESIMPULAN}

Tujuan dari penelitian ini untuk mendeskripsikan dan menganalisa strategi komunikasi dari Petugas Penyuluh perusahaan dalam mensosialisasikan Perjanjian Kerja Bersama karyawan di kebun Ujung Lamie. Kemudian strategi komunikasi penyuluhan PT. Agro Sinergi dalam mensosialisasikan Perjanjian Kerja Bersama (PKB) oleh direksi PT. Agro Sinergi Nusantara (PT. ASN) dengan menjalankan aspek perencanaan komunikasi meliputi pengenalan internal perusahaan dan eksternal perusahaan, memberikan materi penyuluh, memilih media komunikasi yang tepat dalam dalam melaksanakan sosialisasi PKB dengan strategy communication tepat sasaran.

Adanya strategi yang baik dapat meningkatkan program yang telah direncanakan oleh perusahaan agar berjalan lancar dari strategi penyuluhan yang telah ditetapkan dengan melakukan sosialisasi dari pihak perusahaan terhadap para pekerja.

Perubahan perilaku dari communication penyuluh perusahaan PT. Agro Sinergi Nusantara bukan dengan adanya rekomendasi dan perintah melainkan dengan penyuluh. Pelaksanaan sosialisasi pada pendekatan psikologi dengan direktur utama, manager dan Subbag SDM. Adanya strategi yang baik dapat meningkatkan program yang telah direncakan oleh perusahaan dapat berjalan lancar melalui strategi penyuluhan dengan melakukan sosialisasi dari pihak perusahaan.

Strategy communication yang dilakukan oleh PT. Agro Sinergi Nusantara terhadap perjanjian kerja bersama dengan karyawan sudah terealisasi dengan baik dan tidak ada hambatan dalam proses pelaksanaan sosialisasi tersebut demi kepentingan bersama. 


\section{DAFTAR PUSTAKA}

Amanah, Siti. Makna Penyuluhan Dan Transformasi Perilaku Manusia. Jurnal $\begin{array}{llll}\text { Penyuluhan, } 2020 . & 03 & \text { (01). }\end{array}$ https://doi.org/10.25015/penyuluhan.v3i1.2152

Arifin, Anwar. Strategi Komunikasi: Sebuah Pengantar Ringkas. Bandung: PT. Armico, 2004.

Bungin, Burhan. Analisis Data Penelitian Kualitatif. Jakarta: Kencana, 2007. . Penelitian Kualitatif: Komunikasi, Ekonomi, Kebijakan Publik dan Ilmu Sosial Lainnya. Jakarta: Kencana, 2010.

Cangara, Hafied. Perencanaan dan Strategi Komunikasi. Jakarta: Raja Grafindo, 2013.

Effendy, Onong Uchjana. Ilmu Komunikasi Teori dan Praktek. Bandung: PT. Remaja Rosdakarya, 2007. Remaja Rosdakarya, 2011.

Kencana, 2014.

Perencanaan Dan Strategi Komunikasi. Jakarta: PT.

Milles, Huberman. Analisis Data Kualitatif, Jakarta: Universitas Indonesia Press, 1992.

Ruben 2013. Perjanjian Kerja Bersama Dilihat Dari Undang-Undang Nomor 13 Tahun 2003 Tentang Ketenagakerjaan.vol.1 No.1. Hal: 117

R. Wayne Pace, Brent D. Peterson, dan M. Dallas Burnett 2018. Strategi Komunikasi Petugas Penyuluhan Pertanian dalam Meningkatkan Hasil Komoditas Tanaman Padi pada Kelompok Tani Purwa Jaya Kabupaten Penajam Paser Utara

Ruslan, Rosady. Manajemen Public Relations dan Media Komunikasi. Jakarta: Rajawali Pers, 2008.

Sugiyono. Metode Penelitian Kuantitatif, Kualitatif, dan R\&D. Bandung: Alfabeta, 2014.

Tobing, Bisma Aristya Lumban, \& Buwana, Sudibyo Aji Narendra. 2016. Perspektif Perjanjian Kerja Bersama Dalam Memotivasi Pekerja. Jurnal Ilmiah Bisnis dan Keuangan, 06 (01). Hlm.1-12. 